\title{
Note on Sources
}

CITATIONS of Descartes's works are, first, to the volume and page number of the new French edition, Oeuvres de Descartes, ed. Ch. Adam and P. Tannery, rev. ed. (Paris: J. Vrin/C.N.R.S., 1964-76), and, second, to the volume and page number of The Philosophical Writings of Descartes, trans. J. Cottingham, R. Stoothoff, and D. Murdoch, 3 vols. (Cambridge: Cambridge University Press, 1985-9I). Except where I indicate otherwise, I adhere to these translations. 

(303용

\section{Descartes's Moral Theory}


